\title{
Å behandle hiv i høyendemisk område
}

Jeg arbeidet nylig som lege ved Senkantana centre i Lesotho. Ved denne klinikken behandles voksne med hiv. Før de hivsmittede får behandling, deltar de i undervisning og må bestå en kunnskapstest. Slik ønsker man å sikre god etterlevelse.

\section{Torunn Nygård}

torunnyg@frisurf.no

Nordlandssykehuset

Smittevern/infeksjonsmedisin

Sorgenfrigaten $20 \mathrm{~B}$

0365 Oslo

I 2008 arbeidet jeg tre måneder som lege ved Senkantana centre i regi av Nordic Secure the Future, et humanitært hjelpearbeid i regi av Bristol-Myers Squibb.

\section{Bakgrunn}

Lesotho er et kongedømme i det sørlige Afrika, omgitt av Sør-Afrika på alle kanter. Det er et av fă land i Afrika som ikke har vært kolonisert, men i perioden 1884-1966 var landet engelsk protektorat. Lesotho er et fjelland, og hele landet ligger over $1000 \mathrm{~m}$ o.h. Ressursgrunnlaget er begrenset og avhengigheten av Sør-Afrika sterk. Om lag en firedel av den yrkesaktive befolkningen er sysselsatt i Sør- Afrika, mange i gruvene $(1,2)$. Ifølge de lokale avisene og dem jeg snakket med i Lesotho, er det vanlig at pendlerne kommer hjem til familien en langhelg hver annen eller hver tredje måned. De har 3-4 uker ferie i året. Pendlerlivet har vært med på å prege Lesothos kultur. Lesotho Highlands Water Project, Afrikas største ingeniørarbeid, har også skapt mange arbeidsplasser. Vann ledes i tunnel via hydroelektrisk kraft til SørAfrika og forsyner store områder i og rundt Johannesburg med vann. Lesotho tjener 24 millioner rand (20 millioner norske kroner) per måned på denne eksporten (1). Til tross for vannprosjektet og arbeidsplasser i SørAfrika antas arbeidsledigheten å være på over 45 \% (2002) (3). De som har arbeid må ofte betale utgiftene både for sin egen kjernefamilie og for søsken og deres familie.

Sammenliknet med andre land i Afrika og med land med tilsvarende levestandard

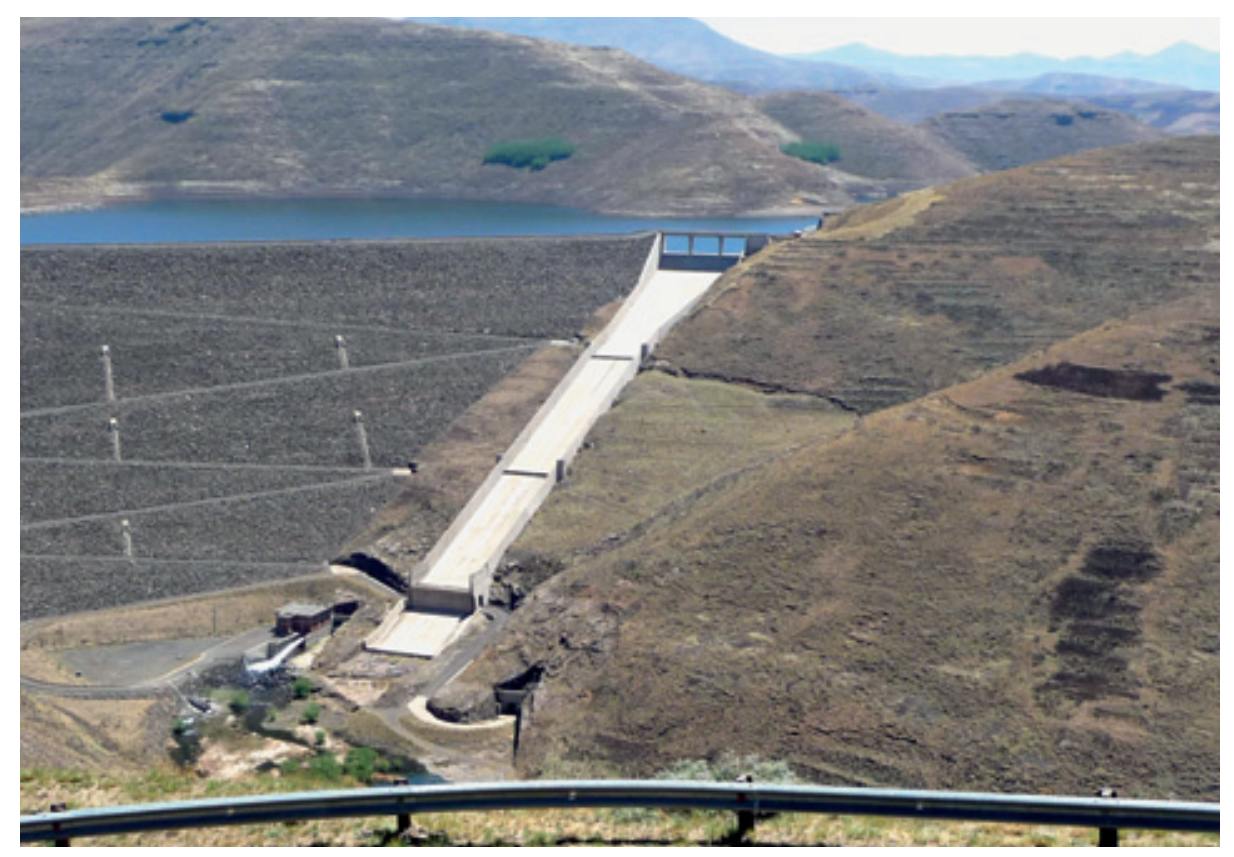

Mohale dam er 153 m høy og ble ferdigstilt i 2002. Sammen med Katse dam er den en del av Lesotho Highland Water Project, som forsyner store deler av Sør-Afrika i og rundt Johannesburg med vann. Begge foto T. Nygård er analfabetismen lav i Lesotho. Ifølge FNs tall synker analfabetismen gradvis, og i 2003 var den $15 \%$ (4). De katolske misjonærene startet etter hvert folkeskoler rundt om i hele Lesotho. I dag er grunnskolen gratis for alle, men ikke obligatorisk. Langt de fleste går noen år på skole. Flere jenter enn gutter fullfører sjuårig grunnskole. Noen gutter får ikke skolegang fordi foreldrene mener de trenger dem til gjetere.

Over $80 \%$ av befolkningen er kristne, over halvparten av dem katolikker $(1,4)$. De fleste går til gudstjeneste hver søndag. Jeg var til stede et par søndager. Kirken var helt full - jeg var den eneste hvite. Alle var pent kledd. Salmesangen fylte hele kirken. Det var flott.

I Lesotho var det fra gammelt av vanlig å ha flere koner. Dette forsøkte særlig protestantene å sette en stopper for. Ifølge historiker Stephen J. Gill konverterte en del til katolisismen fordi de opplevde at katolisismen gikk bedre overens med flerkoneri, som de ikke ville gi avkall på (5). Det er fortsatt vanlig med flere partnere, både blant kvinner og menn. En del skiller seg og gifter seg på ny, mens de fleste forblir gift med samme ektefelle, men har flere seksualpartnere samtidig (1).

\section{Helseforhold}

Lesotho har fem leger per 100000 innbyggere. Til sammenlikning har Sør-Afrika 65 leger per 100 000, mens i Norge har vi 445. Fordelingen av sykepleiere og jordmødre er tilsvarende. Folketallet falt fra 2,2 millioner innbyggere i 2004 til 1,8 millioner i 2007. I samme periode falt gjennomsnittlig levealder fra 44 år til 38 år. De fleste er døde av hiv og/eller tuberkulose og for mange barn dør av andre infeksjonssykdommer. Hver dag dør gjennomsnittlig 70 mennesker av hivrelatert sykdom og 1-2 i trafikken. $28 \%$ av befolkningen er hivpositive, de fleste av dem er mellom 15 og 35 år. Man antar at det er ca. 12000 hivpositive barn. Heldigvis finnes det lyspunkter: I hovedstaden har hivsmitte fra mor til barn i forbindelse med graviditet, fødsel og amming falt fra over $30 \%$ for kun $3-4$ år siden til ca. $10 \%$ i dag, og stadig flere får god hivbehandling $(3,6)$.

Lesotho er blant de landene i verden med høyest forekomst av tuberkulose, 513 per 100000 (4) og med multiresistent tuberkulose i over $10 \%$ av tilfellene. $80 \%$ av dem med tuberkulose har i tillegg hiv. Mange unge voksne dør, og mange barn blir foreld- 
reløse. Det finnes en SOS-barneby og et barnehjem for mishandlede barn utenfor Maseru. Jeg fikk besøke en barneskole sør i landet. $1 / 3$ av barna var foreldreløse. Disse barna ble tatt hånd om av slektninger, ofte eldre søsken, eller naboer.

\section{Senkatana centre}

Senkatana centre hvor jeg arbeidet i regi av Nordic Secure the Future, er en klinikk i hovedstaden Maseru som behandler voksne (over 18 år) med hiv. Det finnes en tilsvarende klinikk for barn. Bristol-Myers Squibb startet klinikkene i samarbeid med myndighetene i Lesotho og lokale helsearbeidere i 2004. De betaler lønningene til alle ansatte, og det offentlige i Lesotho betaler alle medisiner og øvrige utgifter. Klinikken står fritt i forhold til BristolMyers Squibb ved valg av medikamenter. Konsultasjoner og medisiner er gratis for alle pasientene ved denne klinikken, men de må betale for eventuell transport.

Klinikken består av en direktør som er lege og en administrerende leder, to behandlende leger og to sykepleiere, en IT-kyndig, tre «farmasøyter», tre bioingeniører, en ernæringskyndig og flere sekretærer og undervisere. Jeg var den eneste utlendingen. Pasientene kommer fra alle lag av befolkningen. Vi var fire behandlere som til sammen konsulterte 120-230 pasienter hver dag. Takket være tålmodige pasienter og et godt innarbeidet og velfungerende system kunne vi håndtere et så høyt antall pasienter. Vi snakket med hver enkelt pasient og bevilget ekstra tid der det var nødvendig. Pasientene reiste hjemmefra mellom kl 4 og kl 5 om morgenen for å komme til konsultasjon. De stilte seg først $\mathrm{i} \mathrm{k} \varnothing$ for registrering. Etter registrering sto de i en ny kø for veiing, blodtrykksmåling, respirasjonsfrekvens og puls. Deretter sto de i kø for å komme til sykepleier eller lege. Etter konsultasjonen var det en siste kø på apoteket. En uke på forhånd kom pasientene til blodprøvetaking. De fleste analysene ble gjort i Lesotho. Ved behov for spesialanalyser ble blodprøver sendt til SørAfrika. Grunnet høye priser måtte vi begrense disse analysene til et absolutt minimum.

Etter første konsultasjon hvor det ble funnet indikasjon for hiv-behandling, fikk pasienten smågruppeundervisning som varte ca. en time. De fikk informasjon om hiv og hivbehandling. Etter undervisningen måtte de besvare en prøve med ca. 20 spørsmål. Bestått test var en forutsetning for å få behandling. De som ikke besto testen, fikk ny undervisning/informasjon inntil de klarte å bestå. Ved eventuelle leseog skrivevansker fikk pasientene alltid hjelp. Årsaken til denne undervisningen med «eksamen» er å sikre god etterlevelse, at pasientene er observante og sier fra ved alvorlige bivirkninger og å øke kunnskapen om hiv og smittemåter. Med få behandlere

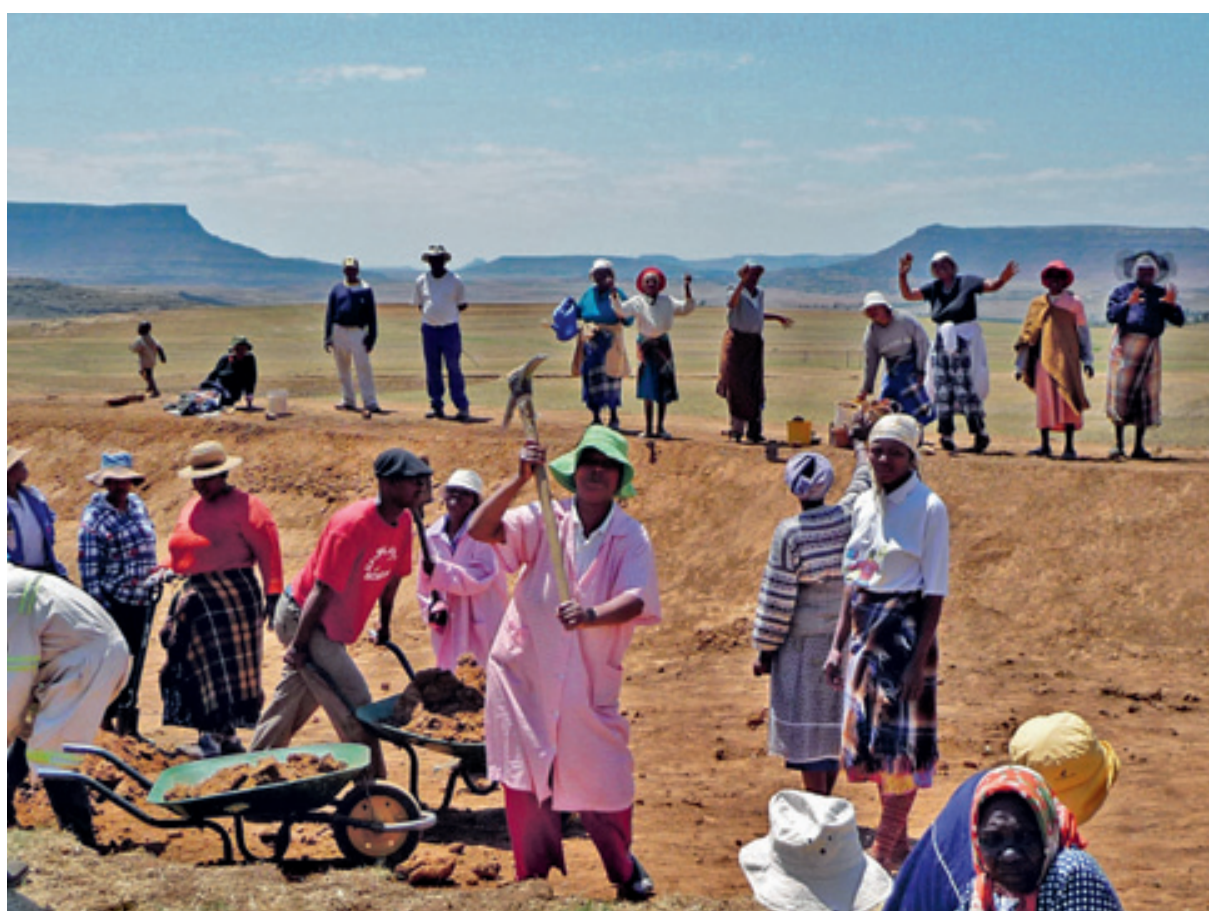

Arbeid på marken. Jordbruk drives opp til 2700 m o.h.

som skal nå mange pasienter med et komplisert behandlingsopplegg, var denne undervisningen med test effektivt. Ifølge mine kollegaer var det få som ikke fulgte opp behandlingen og kontrollene, og dette var også mitt inntrykk. De som ikke fulgte opp, var nesten alltid pasienter som var redd for å bli sparket fra arbeidet, dersom arbeidsgiver fikk vite at de hadde hiv.

De kviet seg for å be om fri for å gå til kontroll. Dette gjaldt både dem som arbeider i Lesotho og i Sør-Afrika. Folk fra Lesotho som arbeider i Sør-Afrika, må betale selv dersom de velger å bli fulgt opp med kontroller og behandling i Sør-Afrika. I starten kommer pasientene til kontroll hyppig, en gang i måneden og annenhver måned. Etter et halvt år under behandling er det vanlig med kontroll hver tredje måned og etter hvert en gang per halvår.

Vi behandlet pasientene både for hiv $o g$ de eventuelle andre plagene som vi var i stand til å gjøre noe med. Vi diagnostiserte tuberkulose flere ganger om dagen. Pasientene må reise med buss til Queen Elisabeth the II, som er det største sykehuset i Lesotho og stå i kø i timevis for å ta røntgenbilde, for så å komme tilbake til oss senere for å få tolket dem. På samme turen leverte de prøver til tuberkulosedyrking. Munnbind var og er mangelvare. Vi hadde ikke lystavle til å se på røntgenbildene, men måtte se på bildene opp mot lampen eller vinduet, eventuelt gå ut. Klinikken behandler kun polikliniske pasienter. Ved behov for innleggelse eller annen spesialistbehandling henviste vi pasienten til aktuelle sykehus, hovedsakelig Queen Elisabeth the II Hospital. Noen trengte behandling som ikke var tilgjengelig i Lesotho. For å få dekket sykehusbehandling i Sør-Afrika, må henvisningen skje via et av de offentlige sykehusene i Lesotho.

I min tid ved Senkatana centre var de fleste pasientene i relativt god form, dvs. de klarte å komme seg til klinikken på beina eller med bussen, og de klarte å sitte på en stol under konsultasjonene. Det var gjennomsnittlig en om dagen som måtte bli båret eller trillet i trillebår eller rullestol. Ut fra journalnotatene og hva mine medarbeidere fortalte, har jeg forstått at pasientene var betydelig sykere tidligere, særlig i 2003 og 2004.

Noe jeg fortsatt ikke forstår, er hvordan så mange som har mistet ektefellen sin og ett av, flere av eller alle barna sine, kun er satt ut av spill noen få uker, og så fortsetter livet. De fleste over 30 år er enker eller enkemenn.

\section{Oppgitte interessekonflikter: Ingen}

\section{Litteratur}

1. Fitzpatrick M, Armstrong K, Blond B et al. SouthAfrica, Lesotho \& Swaziland. London: Lonely Planet, 2008.

2. Store norske leksikon. Lesotho. www.snl.no/ Lesotho (18.11.2009).

3. Globalis. Lesotho. FNs tusenårsmål. www.globalis.no/Land/Lesotho/(show)/mdg (18.11.2009).

. Globalis. Lesotho. Statistikk. www.globalis.no/ Land/Lesotho/(show)/indicators (16.11.2009).

5. Gill SJ. A short history of Lesotho: from the late Stone age until the 1993 elections. Morija, Leso tho: Morija Museum \& Archives, 1993.

6. Wikipedia. Lesotho. http://no.wikipedia.org/wiki/ Lesotho (6.11.2009).

Manuskriptet ble mottatt 6.2. 2009 og godkjent 27.11. 2009. Medisinsk redaktør Siri Lunde. 